\title{
Type 2 Diabetes Treatment Recommendations Update: Appropriate Use of Dipeptidyl Peptidase-4 Inhibitors
}

Susan Cornell*

Midwestern University, Chicago College of Pharmacy, Downers Grove, IL, USA

\begin{abstract}
In this article, recommendations from the 2012 American Diabetes Association (ADA)/European Association for the Study of Diabetes (EASD) position statement are discussed with an emphasis on the appropriate use of Dipeptidy Peptidase-4 (DPP-4) inhibitors in individuals with Type 2 Diabetes Mellitus (T2DM). The 2012 ADA/EASD position statement emphasizes individualization of treatment, with glycated hemoglobin (A1C) targets being determined for each patient based on life expectancy, complications, disease duration, comorbidities, such as cardiovascular disease or cognitive impairment, and the risk of hypoglycemia and other adverse events. Patients' attitudes and support systems should also be considered. Recommendations for pharmacotherapy are less prescriptive and should be based on a patient's needs, preferences, and tolerances. In general, metformin is recommended as firstline therapy for most patients, although combination of 2 noninsulin agents or insulin alone should be considered in patients with baseline $A 1 C \geq 9.0 \%$. Add-on therapy to metformin will likely be needed to achieve and maintain glycemic control as the disease progresses. It is important to avoid therapies that increase the risk of weight gain or and, especially in older patients, hypoglycemia. As discussed in this review, DPP-4 inhibitors are well tolerated and effectively lower $\mathrm{A} 1 \mathrm{C}$ and improve $\beta$-cell function without increasing the risk of hypoglycemia and weight gain. DPP4 inhibitors are recommended as an option for first-line therapy when metformin is contraindicated or not tolerated and are also recommended as an option for add-on therapy to metformin and to metformin plus a sulfonylurea, a thiazolidinedione, or insulin. This article reviews the appropriate use of DPP-4 inhibitors in individuals with T2DM and recently published cardiovascular outcome trials with DPP-4 inhibitors.
\end{abstract}

Keywords: Dipeptidyl peptidase-4 (DPP-4) inhibitor; Glycated hemoglobin (A1C); Pharmacotherapy; Treatment goals; Hypoglycemia; Weight gain; Metformin

\section{Introduction}

Patients with Type 2 Diabetes Mellitus (T2DM) are at an increased risk for heart disease, stroke, dementia, and Alzheimer's disease $[1,2]$. In patients with newly diagnosed (T2DM), intensive control of hyperglycemia can prevent or delay the onset of microvascular complications (ie, nephropathy, retinopathy, and neuropathy) [3]. However, T2DM is a heterogeneous disease, and results from recent clinical trials in patients with established T2DM and Cardiovascular (CV) disease or CV risk factors suggest that not all patients with T2DM will experience improved CV and cognitive outcomes from intensive glycemic control, especially older patients with comorbidities and those with a long duration of uncontrolled T2DM [4-10].

In 2012, the American Diabetes Association (ADA) and the European Association for the Study of Diabetes (EASD) published a position statement containing updated recommendations for the management of hyperglycemia in patients with T2DM [11]. Compared with previous consensus statements, the new updated position statement emphasizes personalized treatment and contains more information regarding the efficacy and safety of newer antihyperglycemic agents, such as the incretin-based dipeptidyl peptidase-4 (DPP-4) inhibitors and glucagon-like peptide-1 (GLP-1) receptor agonists, and provides recommendations for their optimal use [12] (Table 1).

DPP-4 inhibitors are oral agents that achieve glycemic control with a low risk of hypoglycemia or weight gain [13]. Those approved for use in the United States are sitagliptin, saxagliptin, linagliptin, and alogliptin, and others are in development. This article reviews the appropriate use of DPP-4 inhibitors in individuals with T2DM based on the current recommendations contained in the 2012 ADA/EASD position statement and also reviews recently published CV outcome trials with DPP-4 inhibitors.

\section{Emphasis on Patient-Centered Care}

The new recommendations emphasize individualized treatment and promote the adoption of patient-centered care in the management of T2DM [11]. Choices of lifestyle modifications and treatment interventions are best made in consultation with the patient, taking into account their comorbidities, commitment level, available resources, and treatment side effects. The emphasis has shifted from tight control of glycated hemoglobin (A1C) levels for all people with T2DM, to treatment based on individual patient needs, preferences, and tolerance. Patients may achieve better control of A1C when their treatment is individualized. Patients who take an active role in their diabetes management may have improved understanding of and adherence to their therapy [14].

\section{Therapy Goals and Treatment Regimens}

The ADA/EASD position statement recommends a general goal of $\mathrm{A} 1 \mathrm{C}<7.0 \%$ for most patients. However, $\mathrm{A} 1 \mathrm{C}$ goals may vary with patient characteristics. For example, a goal of $6.0 \%$ to $6.5 \%$ may be more appropriate for newly diagnosed patients with a long life expectancy and no significant CV disease or other comorbidities, if achievable without significant hypoglycemia or other adverse effects. In contrast,

${ }^{*}$ Corresponding author: Susan Cornell, PharmD, Midwestern University, Chicago College of Pharmacy, 555 W 31 Street - AH 355, Downers Grove, IL 60515, USA Tel: 630-515-6191; Fax: 630-515-6103; E-mail: SCORNE@midwestern.edu

Received May 07, 2014; Accepted August 11, 2014; Published August 19, 2014

Citation: Cornell S (2014) Type 2 Diabetes Treatment Recommendations Update: Appropriate Use of Dipeptidyl Peptidase-4 Inhibitors. J Diabetes Metab 5: 414 doi:10.4172/2155-6156.1000414

Copyright: () 2014 Cornell S. This is an open-access article distributed under the terms of the Creative Commons Attribution License, which permits unrestricted use, distribution, and reproduction in any medium, provided the original author and source are credited. 


\begin{tabular}{|c|c|c|}
\hline & 2009 [12] & $2012[11]$ \\
\hline General & $\begin{array}{l}\text { Consensus approach to help healthcare } \\
\text { providers choose the most appropriate } \\
\text { interventions for patients with T2DM. Lifestyle } \\
\text { intervention is important. }\end{array}$ & $\begin{array}{l}\text { Less prescriptive, patient centered. Patient and disease factors drive } \\
\text { decision making. Age and comorbidities may impose constraints on } \\
\text { disease management. Lifestyle intervention is important. }\end{array}$ \\
\hline Glycemic target (A1C) & $<7.0 \%$ for most patients & $\begin{array}{l}<7.0 \% \text { for most patients } \\
<6.5 \% \text { for patients with short disease duration, long life expectancy, no } \\
\text { significant CVD } \\
7.5 \%-8.0 \% \text { for patients with limited life expectancy, advanced } \\
\text { complications, comorbidities, history of hypoglycemia, and difficulty } \\
\text { maintaining glycemic target. }\end{array}$ \\
\hline Initial drug therapy & $\begin{array}{l}\text { Metformin } \\
\text { If symptomatic hyperglycemia persists, rapid } \\
\text { addition of other diabetes medications should } \\
\text { be considered. }\end{array}$ & $\begin{array}{l}\text { Metformin } \\
\text { If } A 1 C \geq 9.0 \% \text {, initiate with } 2 \text { noninsulin drugs or insulin. } \\
\text { If } A 1 C \geq 10.0 \% \text {, initiate insulin }\end{array}$ \\
\hline $\begin{array}{l}\text { Alternative to metformin if contraindicated or } \\
\text { not tolerated }\end{array}$ & Not addressed & $\begin{array}{l}\text { SU, pioglitazone, DPP-4 inhibitor. (GLP-1 receptor agonist if weight loss } \\
\text { is essential) }\end{array}$ \\
\hline 2-drug combinations & $\begin{array}{l}\text { Metformin+SU } \\
\text { Metformin+basal insulin }\end{array}$ & $\begin{array}{l}\text { Metformin+SU } \\
\text { Metformin+TZD } \\
\text { Metformin+DPP-4 inhibitor } \\
\text { Metformin+GLP-1 receptor agonist } \\
\text { Metformin+insulin }\end{array}$ \\
\hline Additional Rx needed to reach glycemic goal & Start or intensify insulin therapy & 3-drug combinations (Figure 1) and/or insulin \\
\hline
\end{tabular}

$\mathrm{A} 1 \mathrm{C}=$ glycated hemoglobin; $\mathrm{CVD}=$ cardiovascular disease; DPP-4=dipeptidyl peptidase-4; GLP-1=glucagon-like peptide-1; SU=sulfonylurea; T2DM=type 2 diabetes mellitus; TZD=thiazolidinedione.

Table 1: Comparison of ADA/EASD 2009 and 2012 Treatment Recommendations.

a less stringent $\mathrm{A} 1 \mathrm{C}$ goal of $7.5 \%$ to $8.0 \%$ may be more appropriate in for patients with a longer duration of T2DM, especially if not well controlled, and for patients with limited life expectancy, advanced complications, extensive comorbidities, such as CV disease or cognitive impairment, history of severe hypoglycemia, and difficulty in achieving and maintaining glycemic goals, despite intensive counseling and use of multiple diabetes medications [9].

Weight reduction or control and exercise are critical components of any program designed to manage T2DM. In patients with T2DM, intensive lifestyle interventions (diet and exercise), especially when started early in the disease process, can produce significant weight loss, improvements in glycemic control, and a reduction in CV risk factors [15]. However, lifestyle changes, particularly weight reduction, are difficult to maintain over the long term, and most individuals with T2DM will require pharmacotherapy to control their hyperglycemia $[16,17]$.

\section{Antihyperglycemic Agents: Characteristics}

The historic course of pharmacotherapy for patients with T2DM usually begins with a single oral agent, followed by combinations of 2 and maybe 3 noninsulin medications. As $\beta$-cell function progressively decreases, patients usually require insulin in combination with 1 or 2 noninsulin agents [11].

There are 11 classes of diabetes medications, in addition to various insulin analogs. The most commonly used noninsulin classes included in the pharmacotherapy algorithm are biguanides, sulfonylureas (SUs), thiazolidinediones (TZDs), DPP-4 inhibitors, and GLP-1 receptor agonists.

\section{Biguanide}

For the past decade, metformin has been the most widely used diabetes drug and is generally considered to have the most favorable benefit-to-risk profile [18]. The primary mechanism of action of metformin is to decrease hepatic glucose production [19]. Compared with diet, metformin treatment (maximum dose of $2550 \mathrm{mg} / \mathrm{d}$ ) of overweight patients with T2DM in the United Kingdom Prospective Diabetes Study (UKPDS) resulted in a reduced risk for myocardial infarction, macrovascular complications, any diabetes-related end point, diabetes-related death, and all-cause death [20]. When used as monotherapy, metformin ( 1000 to $\geq 1500 \mathrm{mg} / \mathrm{d}$ ) reduces $\mathrm{A} 1 \mathrm{C}$ by $-0.5 \%$ to $-1.8 \%$ and is associated with a low risk of hypoglycemia or weight gain $[18,20,21]$. The most common adverse events with metformin are nausea, diarrhea, and cramping [22]. Metformin is eliminated unchanged primarily by the kidneys and is contraindicated in individuals with decreased kidney function [23].

\section{Sulfonylureas/Meglitinides}

SUs and meglitinides interact with similar but distinct receptors on the pancreatic $\beta$ cell, resulting in increased insulin secretion [22]. SUs are long-acting secretagogues that target Fasting Plasma Glucose (FPG) and Postprandial Plasma Glucose (PPG), thereby providing an effective lowering of A1C of up to $-1.25 \%$ [24]. Meglitinides are short-acting secretagogues that have a faster onset of action and a shorter half-life than SUs and require more frequent dosing [22,25]. Meglitinides reduce A1C by up to approximately $-1.0 \%$ [24]. The durability of glycemic control with SUs tends to be shorter than that of metformin or TZDs, and SUs can be associated with weight gain, hypoglycemia $[3,18]$. and increased CV risk [26]. However, the shorter-acting meglitinides may be associated with less hypoglycemia than SUs [18,26,27].

\section{Thiazolidinediones}

TZDs increase insulin sensitivity, are effective at lowering FPG and PPG, and provide durability in maintaining A1C [24,28,29]. Typically, TZDs lower A1C by up to $-1.0 \%$ to $-1.5 \%$ [24]. TZDs, particularly pioglitazone, have favorable effects on lipids and improve $\beta$-cell function [29-32]. Disadvantages of TZDs include weight gain, increased fractures, edema, and heart failure in susceptible individuals $[29,33]$. In recent years, the safety of TZDs has come under increased scrutiny as a result of a possible increased risk of myocardial infarction with rosiglitazone that led to its restricted use in the United States and its complete removal from the European market [34-36]. In addition, a 
possible increased risk of bladder cancer with pioglitazone, especially in those taking the drug for $>2$ years, has been reported $[37,38]$.

\section{Newer Agents}

Recently approved agents include GLP-1 receptor agonists and DPP-4 inhibitors that act through the incretin system. The incretin hormones GLP-1 and Glucose-Dependent Insulinotropic Polypeptide (GIP) are secreted by the intestine into the circulation in response to a meal. Both hormones stimulate glucose dependent insulin secretion, and GLP-1 also suppresses glucagon secretion, delays gastric emptying, and increases feelings of satiety, leading to decreased food intake [39]. GLP-1 and GIP are rapidly degraded by DPP-4, an enzyme present as both a circulating and membrane-bound form expressed in many tissues $[39,40]$. In individuals with T2DM, the insulinotropic effect of GLP-1 is preserved, whereas the response of $\beta$ cells to GIP is reduced [41]. Two approaches have been developed to increase the levels of GLP-1. GLP1 receptor agonists are injectable, degradation-resistant GLP-1 agents with prolonged half-lives, compared with native GLP-1 [39]. DPP-4 inhibitors are oral agents that stabilize the endogenous postprandial levels of GLP-1 by inhibiting the degradation of GLP 1 [39]. In addition to inactivating GLP-1 and GIP, DPP-4 is also involved in the degradation of other peptides that are important in CV regulation, such as stromal cell-derived factor-1 $\alpha$ (SDF-1 $\alpha$ ), which is involved in the recruitment of bone marrow-derived Endothelial Progenitor Cells (EPCs) to sites of vascular damage and B-type natriuretic peptide, which plays a role in volume regulation [42-44]. Whether preventing the inactivation of peptides other than the incretin hormones is important in the action of DPP-4 inhibitors in patients with T2DM requires additional study.

\section{Glucagon-like peptide-1 receptor agonists}

Exenatide and liraglutide are currently approved GLP-1 receptor agonists that mimic the actions of endogenous GLP-1 and improve glycemic control when used in combination with metformin, SUs, TZDs, or basal insulin in patients with T2DM [45-48]. Improvements in $\beta$-cell function have also been reported $[46,49]$. GLP-1 receptor agonists are typically associated with weight loss and have a low risk of hypoglycemia [45-48], although the frequency of hypoglycemia may increase when these agents are used in combination with an SU or insulin [50-54]. Significant decreases in systolic blood pressure of 4 to 6 $\mathrm{mm} \mathrm{Hg}$ have been observed in clinical trials of GLP-1 receptor agonists $[45,46]$. When used with basal insulin, there is the potential to lower daily insulin requirements [45]. Gastrointestinal effects, including nausea and vomiting, are the most frequently reported adverse events with GLP-1 receptor agonists [45-48]. GLP-1 receptor agonists are given by injection once or twice daily or once weekly [55].

\section{Dipeptidyl peptidase-4 inhibitors}

By inhibiting the enzyme responsible for the breakdown of GLP1 and GIP, DPP 4 inhibitors prolong the half-life of endogenously released GLP-1 and GIP, leading to enhanced glucose-dependent insulin secretion and decreased glucose-dependent glucagon secretion [39]. Sitagliptin, saxagliptin, linagliptin, and alogliptin are DPP-4 inhibitors approved for use in the United States. DPP-4 inhibitors effectively improve glycemic control (significantly reduce A1C, FPG, and PPG [when measured]) when used as monotherapy [56-59], as add-on to metformin [60-64], as add-on to SUs with or without metformin [65-68], as add-on to TZDs with or without metformin [6971], as add-on to insulin with or without metformin [72-74], and as initial combination with metformin [75] or pioglitazone [76-78]. As monotherapy, reductions in A1C with DPP 4 inhibitors are generally less than those with agents that primarily target FPG, such as metformin or long-acting GLP-1 receptor agonists, but are comparable to those with SUs and TZDs [79]. DPP-4 inhibitors are weight neutral and pose a low risk of hypoglycemia when used as monotherapy [56-59] or as add-on to metformin [60-64]. When added to insulin therapy, they have the potential to lower daily insulin requirements [72]. When DPP4 inhibitors are used in combination with an insulin secretagogue (eg, $\mathrm{SU}$ ) or insulin, a lower dose of the insulin secretagogue or insulin may be required to reduce the risk of hypoglycemia [80]. DPP-4 inhibitors have also been shown to improve $\beta$-cell function $[56-58,60,61,63,66]$.

Common adverse events reported in clinical trials of DPP-4 inhibitors include nasopharyngitis, upper respiratory tract infection, urinary tract infection, and headache [80-82]. However, analysis of clinical trials of $>7000$ patients receiving DPP- 4 inhibitors found that the risk for nasopharyngitis, upper respiratory tract infection, and urinary tract infection was not different between DPP-4 inhibitors and active comparators in these trials [79]. Acute pancreatitis and hypersensitivity reactions (urticaria, angioedema, and localized skin exfoliation) have been reported with the use of DPP- 4 inhibitors in clinical trials and from postmarketing surveillance [80-82].

\section{Other Agents}

Other drugs approved for use in T2DM in the United States include a-glucosidase inhibitors, which slow the digestion and absorption of carbohydrates [83]; colesevelam, a bile acid sequestrant with an unclear mechanism of action [84]; the dopamine agonist bromocriptine, which affects the central control of metabolism [85]; pramlintide, an amylin agonist used in conjunction with insulin [86]; and canagliflozin [87], a Sodium-Glucose Cotransporter-2 (SGLT2) inhibitor that reduces reabsorption of filtered glucose and lowers the renal threshold for glucose, resulting in increased urinary glucose excretion [88]. SGLT2 inhibitors have a low risk of hypoglycemia and are associated with reductions in body weight and blood pressure [89].

\section{Pharmacotherapy: General Recommendations}

$\mathrm{T} 2 \mathrm{DM}$ is a progressive disease that results from the continual decrease in $\beta$-cell function [90]. Consequently, most patients require intensification and adjustments of treatment with multiple agents and insulin during the course of the disease to achieve and maintain glycemic control (Figure 1). For example, in the UKPDS trial, 3 years after diagnosis of diabetes and initiation of pharmacotherapy, approximately $50 \%$ of patients failed to achieve a target $\mathrm{A} 1 \mathrm{C}<7.0 \%$ with metformin, SU, or insulin monotherapy. By 9 years, approximately $75 \%$ of patients failed to achieve A1C $<7.0 \%$ with monotherapy [91]. Treatment assessments should be made regularly and therapy adjusted as target $\mathrm{AlC}$ goals are met or missed.

\section{Initial therapy}

Initial therapy for T2DM should be individualized and based on patients' characteristics and preferences, degree of hyperglycemia, potential for $\beta$-cell preservation, side effect profile, and potential for hypoglycemia and weight gain. In general, when diet and exercise alone have not been sufficient to achieve A1C goals, the ADA/EASD position statement recommends that metformin be considered as initial therapy for the majority of patients [11]. If metformin cannot be used, other oral agents to consider as initial therapy include SUs/meglitinides, pioglitazone, or DPP-4 inhibitors. If weight loss is a particular concern, a GLP-1 receptor agonist should be considered. At diagnosis, if patients have $\mathrm{A} 1 \mathrm{C} \geq 9.0 \%, 2$ noninsulin drugs or insulin should be considered as initial therapy instead of metformin monotherapy. When patients 


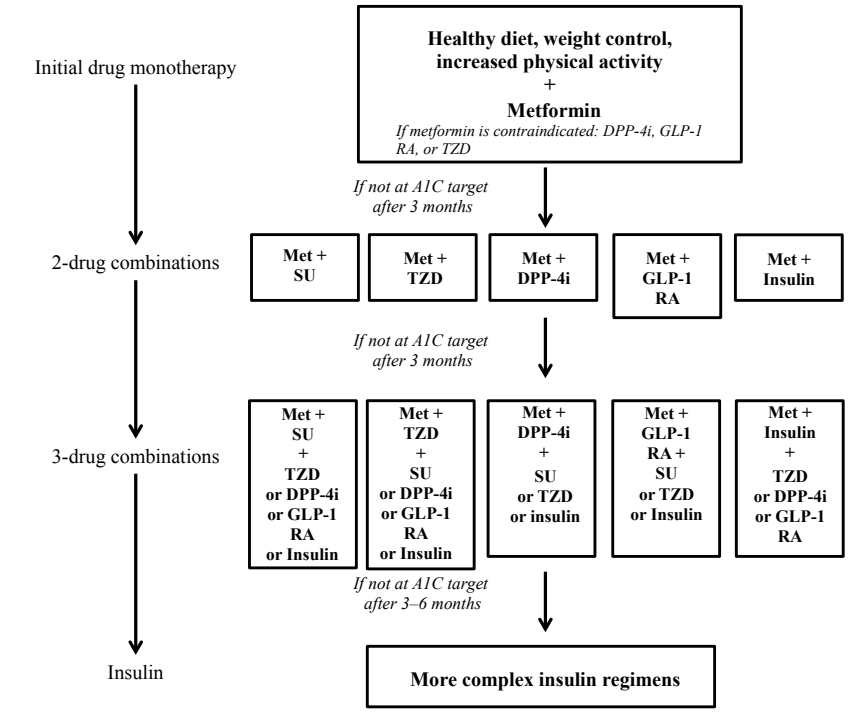

A1C=glycated hemoglobin; DPP-4i=dipeptidyl peptidase-4 inhibitor GLP-1-RA=glucagon-like peptide-1 receptor agonist; $M E T=$ metformin; $\mathrm{SU}=$ sulfonylurea; $\mathrm{TZD}=$ thiazolidinedione.

Figure 1: American Diabetes Association/European Association for the Study of Diabetes general recommendations for pharmacotherapy.

Adapted from Inzucchi et al [11]. Permission pending.

have significant hyperglycemic symptoms or elevated plasma glucose concentrations $(300-350 \mathrm{mg} / \mathrm{dL})$ or $\mathrm{AlC} \geq 10.0 \%$ to $12.0 \%$, insulin is strongly recommended as initial therapy.

\section{Two-drug combinations}

If the A1C goal is not achieved and maintained over the course of approximately 3 months with metformin monotherapy, a second oral agent (SU, TZD, or DPP-4 inhibitor), GLP-1 receptor agonist, or basal insulin (especially if A1C is high) should be added. If glycemic improvement is not apparent, the agent should be discontinued and substituted with another medication with a different mechanism of action. Although cost-effectiveness and long-term outcomes with newer agents remain to be determined, 3 recent meta-analyses have concluded that among noninsulin agents, DPP-4 inhibitors and GLP-1 receptor agonists may be good alternatives to SUs and TZDs as add-on therapy to metformin due to their glycemic efficacy, low risk of hypoglycemia, and weight neutrality or weight reduction $[79,92,93]$.

\section{Three-drug combination}

Studies have shown that the addition of a third noninsulin agent to a 2-drug combination can improve glycemic control in some patients with inadequate control. For example, addition of a TZD [94-98], GLP1 receptor agonist [48], or DPP-4 inhibitor [66,67,99] to metformin plus SU therapy produced additional improvements in glycemic control in patients poorly controlled with metformin and an SU.

However, in patients inadequately controlled on a 2-drug combination with $\mathrm{A} 1 \mathrm{C} \geq 8.5 \%$, the best glycemic response may be achieved by transitioning to insulin. This may be especially appropriate in patients with long duration of disease and major decreases in $\beta$-cell function [100].

\section{Insulin therapy}

Initial insulin therapy usually consists of a single dose of basal insulin with uptitration, if appropriate (Figure 2). As $\beta$-cell function continues

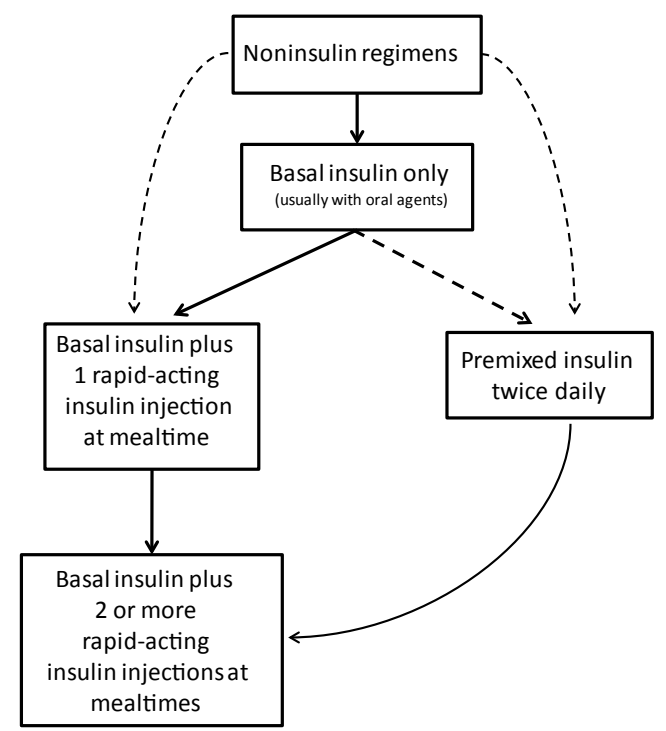

Figure 2: American Diabetes Association/European Association for the Study of Diabetes sequential insulin dosing strategy.

Adapted from Inzucchi et al [11]. Permission pending.

to deteriorate such that PPG exceeds $180 \mathrm{mg} / \mathrm{mL}(10.0 \mathrm{mmol} / \mathrm{L})$, daily basal insulin together with a rapid-acting insulin injection (basal-bolus regimen) should be initiated at the meal identified as producing the greatest increase in blood glucose, which is usually the evening meal [11]. If glycemic control is still not attained, increasing the prandial dose of insulin or starting prandial insulin at the second largest meal or at all 3 meals may be necessary [11]. A less flexible insulin regimen is the use of premixed insulins that consist of intermediate insulin with regular or rapid-acting insulin. Administration is before the morning and evening meals and may be appropriate for individuals who eat regularly and require a simple dosing scheme [11].

Oral agents are often continued with basal insulin. It is important to avoid agents that are associated with weight gain (eg, SUs or TZDs) or hypoglycemia and to consider agents that are weight neutral (eg, metformin or DPP-4 inhibitors) or that are associated with weight loss (eg, GLP-1 receptor agonists). In some patients, the combination of metformin and insulin produced better glycemic control, less weight gain, lower insulin requirements, and similar or less hypoglycemia than insulin alone [101,102]. Another option includes insulin combined with agents that improve PPG, such as GLP-1 receptor agonists and DPP-4 inhibitors. For example, addition of exenatide to insulin therapy reduced $\mathrm{AlC}$ to a greater extent than insulin alone and decreased body weight versus an increase with insulin [45]. The addition of exenatide reduced the daily insulin requirements without increasing the incidence of hypoglycemia. Similarly, DPP-4 inhibitors added to insulin therapy (with or without metformin and/or pioglitazone) produced greater reductions in A1C (sitagliptin, saxagliptin, linagliptin, and alogliptin) and PPG (sitagliptin, saxagliptin, and linagliptin) than ongoing treatment with the insulin regimen alone [72-74,103]. Changes in body weight were similar between the groups taking insulin without versus with DPP-4 inhibitors. The incidence of hypoglycemia was similar across treatment groups $[72,74,103]$ or higher with a DPP-4 inhibitor plus insulin versus insulin alone [73].

\section{ADA/EASD Recommendations: DPP4 Inhibitors}

DPP-4 inhibitors are recommended as an option for first-line 
therapy when metformin is contraindicated or not tolerated (Figure 1) [11]. A combination of 2 noninsulin agents is suggested as an option for initial therapy in patients with a high baseline $\mathrm{A} 1 \mathrm{C}$ who are unlikely to achieve target A1C with monotherapy. Combination of a DPP-4 inhibitor with metformin, shown to be more effective than either agent alone as initial therapy in patients with T2DM, is one option for this patient population $[75,104]$. DPP-4 inhibitors are also recommended as an option for add-on therapy to metformin (dual therapy) and for add-on therapy to metformin and an SU, metformin and a TZD, and metformin and insulin (triple therapy).

\section{Other Considerations}

Patients with T2DM are at increased risk for CV morbidity and mortality [105-107]. One of the goals of the ADA/EASD recommendations is to make comprehensive $\mathrm{CV}$ risk reductions a major focus of therapy. DPP-4 inhibitors represent a treatment option that minimizes the CV risk factors of weight gain and hypoglycemia. Analyses of pooled data from clinical trials with DPP-4 inhibitors suggest that these drugs do not increase $\mathrm{CV}$ risk and may be associated with a decrease in CV events [108-112]. Several large CV outcome trials are addressing the CV effects of DPP-4 inhibitors [113-116]. Two of these trials, Saxagliptin Assessment of Vascular Outcomes Recorded in patients with diabetes mellitus - Thrombosis in Myocardial Infarction 53 (SAVOR-TIMI 53) and EXamination of cAardiovascular outcoMes with alogliptIN versus standard of carE in patients with T2DM and acute coronary syndrome (EXAMINE) have recently been completed $[117,118]$.

SAVOR-TIMI 53 evaluated the cardiovascular safety and efficacy of saxagliptin compared with placebo in patients $(\mathrm{N}=16,492)$ with T2DM and a history of established $\mathrm{CV}$ disease or multiple risk factors for vascular disease (eg, dyslipidemia, hypertension, or active smoking). Patients continued to receive standard-of-care antihyperglycemic (except for other DPP-4 inhibitors or GLP-1 receptor agonists) and $\mathrm{CV}$ disease therapy. Saxagliptin did not increase or decrease the risk of CV death, nonfatal myocardial infarction, or nonfatal ischemic stroke, compared with placebo. Significantly more patients randomized to saxagliptin $(3.5 \%)$ were hospitalized for heart failure compared with placebo (2.8\%; hazard ratio, $1.27 ; 95 \% \mathrm{CI}, 1.07$ to $1.51 ; \mathrm{P}=0.007$ ), although these individuals did not experience an increase in $\mathrm{CV}$ death, nonfatal myocardial infarction, or nonfatal stroke. This finding needs to be further investigated. At study completion (median follow up of 2.1 years), saxagliptin improved glycemic control and reduced the development and progression of microalbuminuria, compared with placebo. The number of patients with acute or chronic pancreatitis was low and similar in both groups (saxagliptin, $0.3 \%$; placebo, $0.3 \%$ ). Five cases of pancreatic cancer were reported in the saxagliptin group versus 12 in the placebo group.

In the EXAMINE trial, patients $(\mathrm{N}=5,380)$ with $\mathrm{T} 2 \mathrm{DM}$ and an acute coronary syndrome within 15 to 90 days before randomization received alogliptin or placebo for a median follow-up of 18 months. Patients continued to receive standard of care for T2DM and CV risk factors. Compared with placebo, alogliptin did not increase or decrease CV death, nonfatal myocardial infarction, or nonfatal stroke. Hospitalization for heart failure was also observed in this trial but occurred with similar frequency in patients receiving alogliptin $(3.9 \%)$ and placebo (3.3\%; hazard ratio, $1.19 ; 95 \% \mathrm{CI}, 0.90$ to $1.58 ; \mathrm{P}=0.22)$ [119]. Alogliptin reduced A1C to a greater extent than placebo (mean change from baseline, $-0.33 \%$ for alogliptin vs $+0.03 \%$ for placebo). Incidences of pancreatitis were similar between alogliptin and placebo. There were no reports of pancreatic cancer.
These studies and other ongoing trials provide valuable information to guide clinicians in choosing among the various antihyperglycemic agents when treating individuals with T2DM and CV disease or at high risk for $\mathrm{CV}$ disease.

\section{Case Report}

\section{Sample patient case}

MG is a 78-year-old, overweight white man with T2DM for 5 years and hypertension for 8 years who is in overall good health. He lives alone at his home of 45 years and does not plan on moving. He tries to eat healthy, is active, and has good support from many family members and friends who live nearby. His current medications include metformin $1000 \mathrm{mg}$ twice daily, lisinopril $20 \mathrm{mg}$ daily, and aspirin $81 \mathrm{mg}$ daily. His $\mathrm{A} 1 \mathrm{C}$ has been in good control (between 6.5\%-7.2\%) during the past 5 years. However, today, MG's A1C is $8.1 \%$. An adherence assessment reveals that MG takes his medications as prescribed and only misses a dose once a month at most.

\section{Therapy approach}

Because MG appears to have a good attitude, a short duration of disease that has been controlled fairly well, few comorbidities, and good support from family and friends, an $\mathrm{A} 1 \mathrm{C}$ goal of $<7 \%$ is appropriate. When selecting add-on pharmacotherapy, the clinician needs to consider that his $\mathrm{A} 1 \mathrm{C}$ is $8.1 \%$; therefore, $\mathrm{PPG}$ may be the major contributor to the elevated $\mathrm{A} 1 \mathrm{C}$, and an agent that targets PPG should be selected.

Additionally, because this patient is older, lives alone, and is overweight, an agent with low hypoglycemic risk and no weight gain would be preferred.

Most DPP-4 inhibitors are available in combination with metformin, such that it may be possible for the patient to take his current metformin medication with a DPP-4 inhibitor in a fixed-dose combination product, reducing concerns regarding adherence.

\section{Summary and Conclusions}

The current ADA/EASD position statement emphasizes individualization of treatment. Diet, exercise, and patient education are important components of any treatment program. Different A1C targets should be considered for each patient based on life expectancy, complications, comorbidities, risk of hypoglycemia and other adverse events, disease duration, and patients' attitudes and support system. Recommendations for pharmacotherapy are less prescriptive and should be based on a patient's needs, preferences, and tolerances. In general, metformin is recommended as first-line therapy for most patients. Add-on therapy to metformin will likely be needed as the disease progresses. It is important to avoid therapies that increase the risk of weight gain and hypoglycemia and do not preserve $\beta$-cell function. Newer therapies such as DPP-4 inhibitors and GLP-1 receptor agonists effectively lower $\mathrm{A} 1 \mathrm{C}$ and improve $\beta$-cell function without increasing the risk of hypoglycemia and weight gain. The clinician and patient should share in the decision-making process concerning treatment goals, as this may improve adherence to therapy.

\section{Author Disclosure Statement and Acknowledgments}

Dr. Cornell has received non-CME honoraria from Johnson \& Johnson Diabetes Insititute and has served on advisory boards for Sanofi, Bristol-Myers Squibb, and AstraZeneca. Medical writing support for the preparation of this manuscript was provided by Richard M. Edwards, $\mathrm{PhD}$, and Janet Matsuura, $\mathrm{PhD}$ from Complete Healthcare Communications, Inc. (Chadds Ford, PA), with funding from Bristol-Myers Squibb and AstraZeneca LP. 
Citation: Cornell S (2014) Type 2 Diabetes Treatment Recommendations Update: Appropriate Use of Dipeptidyl Peptidase-4 Inhibitors. J Diabetes Metab 5: 414 doi:10.4172/2155-6156.1000414

\section{References}

1. Centers for Disease Control and Prevention. National diabetes statistics report: estimates of diabetes and its burden in the United States, 2014

2. Peila R, Rodriguez BL, Launer LJ (2002) Type 2 diabetes, APOE gene, and the risk for dementia and related pathologies: The Honolulu-Asia Aging Study. Diabetes 51: 1256-1262.

3. UK Prospective Diabetes Study Group (1998) Intensive blood-glucose control with sulphonylureas or insulin compared with conventional treatment and risk of complications in patients with type 2 diabetes (UKPDS 33). Lancet 352: 837853.

4. Smith RJ, Nathan DM, Arslanian SA, Groop L, Rizza RA et al. (2010) Individualizing therapies in type 2 diabetes mellitus based on patient characteristics: what we know and what we need to know. J Clin Endocrinol Metab 95: 1566-1574.

5. Duckworth W, Abraira C, Moritz T, Reda D, Emanuele N, et al. (2009) Glucose control and vascular complications in veterans with type 2 diabetes. $\mathrm{N}$ Engl J Med 360: 129-139.

6. Gerstein HC, Miller ME, Byington RP, Goff DC Jr, Bigger JT, et al. (2008) Effects of intensive glucose lowering in type 2 diabetes. N Engl J Med 358: 2545-2559.

7. Patel A, MacMahon S, Chalmers J, Neal B, Billot L, et al. (2008) Intensive blood glucose control and vascular outcomes in patients with type 2 diabetes. $\mathrm{N}$ Engl J Med 358: 2560-2572.

8. Gerstein HC, Miller ME, Genuth S, Ismail-Beigi F, Buse JB, et al. (2011) Longterm effects of intensive glucose lowering on cardiovascular outcomes. N Eng J Med 364: 818-828.

9. Lee SJ, Eng C (2011) Goals of glycemic control in frail older patients with diabetes. JAMA 305: 1350-1351.

10. Launer LJ, Miller ME, Williamson JD, Lazar RM, Gerstein HC, et al. (2011) Effects of intensive glucose lowering on brain structure and function in people with type 2 diabetes (ACCORD MIND): a randomised open-label substudy. Lancet Neurol 10: 969-977.

11. Inzucchi SE, Bergenstal RM, Buse JB, Diamant M, Ferrannini E, et al. (2012) Management of hyperglycemia in type 2 diabetes: a patient-centered approach: position statement of the American Diabetes Association (ADA) and the European Association for the Study of Diabetes (EASD). Diabetes Care 35: 1364-1379.

12. Nathan DM, Buse JB, Davidson MB, Ferrannini E, Holman RR, et al. (2009) Medical management of hyperglycemia in type 2 diabetes: a consensus algorithm for the initiation and adjustment of therapy: a consensus statement of the American Diabetes Association and the European Association for the Study of Diabetes. Diabetes Care 32: 193-203.

13. Amori RE, Lau J, Pittas AG (2007) Efficacy and safety of incretin therapy in type 2 diabetes: systematic review and meta-analysis. JAMA 298: 194-206.

14. Tsapas A, Matthews DR (2008) N of 1 trials in diabetes: making individual therapeutic decisions. Diabetologia 51: 921-925

15. Look AHEAD Research Group, Pi-Sunyer X, Blackburn G, Brancati FL, Bray GA, et al. (2007) Reduction in weight and cardiovascular disease risk factors in individuals with type 2 diabetes: one-year results of the Look AHEAD trial. Diabetes Care 30: 1374-1383

16. Look AHEAD Research Group, Wing RR (2010) Long-term effects of a lifestyle intervention on weight and cardiovascular risk factors in individuals with type 2 diabetes mellitus: four-year results of the Look AHEAD trial. Arch Intern Med 170: $1566-1575$

17. Svetkey LP, Stevens VJ, Brantley PJ, Appel LJ, Hollis JF, et al. (2008) Comparison of strategies for sustaining weight loss: the Weight Loss Maintenance randomized controlled trial. JAMA 299: 1139-1148.

18. Bennett WL, Maruthur NM, Singh S, Segal JB, Wilson LM, et al. (2011) Comparative effectiveness and safety of medications for type 2 diabetes: an update including new drugs and 2-drug combinations. Ann Intern Med 154 602-613.

19. Stumvoll M, Nurihan N, Perriello G, Dailey G, Gerich JE (1995) Metabolic effects of metformin in non-insulin-dependent diabetes mellitus. N Engl J Med 333: 550-554.

20. UK Prospective Diabetes Study (UKPDS) Group (1998) Effect of intensive blood-glucose control with metformin on complications in overweight patients with type 2 diabetes (UKPDS 34). Lancet 352: 854-865.
21. Hirst JA, Farmer AJ, Ali R, Roberts NW, Stevens RJ (2012) Quantifying the effect of metformin treatment and dose on glycemic control. Diabetes Care 35 446-454.

22. Inzucchi SE (2002) Oral antihyperglycemic therapy for type 2 diabetes: scientific review. JAMA 287: 360-372.

23. Glucophage ${ }^{\circledR}$ and Glucophage $\mathrm{XR} \circledast$ (metformin $\mathrm{HCl}$ tablets and metformin $\mathrm{HCl}$ extended-release tablets). Full Prescribing Information, Bristol-Myers Squibb Company, Princeton, NJ, 2009

24. Sherifali D, Nerenberg K, Pullenayegum E, Cheng JE, Gerstein HC (2010) The effect of oral antidiabetic agents on $\mathrm{A} 1 \mathrm{C}$ levels: a systematic review and metaanalysis. Diabetes Care 33: 1859-1864

25. Melander A (2004) Kinetics-effect relations of insulin-releasing drugs in patients with type 2 diabetes: brief overview. Diabetes 53 Suppl 3: S151-155.

26. Roumie CL, Hung AM, Greevy RA, Grijalva CG, Liu X, et al. (2012) Comparative effectiveness of sulfonylurea and metformin monotherapy on cardiovascular events in type 2 diabetes mellitus: a cohort study. Ann Intern Med 157: 601-610.

27. Gerich J, Raskin P, Jean-Louis L, Purkayastha D, Baron MA(2005) PRESERVE beta: two-year efficacy and safety of initial combination therapy with nateglinide or glyburide plus metformin. Diabetes Care 28: 2093-2099.

28. Tonelli J, Li W, Kishore P, Pajvani UB, Kwon E, et al. (2004) Mechanisms of early insulin-sensitizing effects of thiazolidinediones in type 2 diabetes. Diabetes 53: 1621-1629.

29. Kahn SE, Haffner SM, Heise MA, Herman WH, Holman RR, et al. (2006) Glycemic durability of rosiglitazone, metformin, or glyburide monotherapy. N Engl J Med 355: 2427-2443.

30. Goldberg RB, Kendall DM, Deeg MA, Buse JB, Zagar AJ, et al. (2005) A comparison of lipid and glycemic effects of pioglitazone and rosiglitazone in patients with type 2 diabetes and dyslipidemia. Diabetes Care 28: 1547-1554.

31. Gastaldelli A, Ferrannini E, Miyazaki Y, Matsuda M, Mari A, et al. (2007) Thiazolidinediones improve beta-cell function in type 2 diabetic patients. Am J Physiol Endocrinol Metab 292: E871-883.

32. Kahn SE, Lachin JM, Zinman B, Haffner SM, Aftring RP, et al. (2011) Effects of rosiglitazone, glyburide, and metformin on beta-cell function and insulin sensitivity in ADOPT. Diabetes 60: 1552-1560.

33. Nesto RW, Bell D, Bonow RO, Fonseca V, Grundy SM, et al. (2003) Thiazolidinedione use, fluid retention, and congestive heart failure: a consensus statement from the American Heart Association and American Diabetes Association. October 7, 2003. Circulation 108: 2941-2948.

34. Nissen SE, Wolski K (2007) Effect of rosiglitazone on the risk of myocardial infarction and death from cardiovascular causes. N Engl J Med 356: 2457 2471.

35. European Medicines Agency: Suspension of rosiglitazone-containing medicines

36. US Food and Drug Administration. FDA Drug Safety Communication: Avandia (rosiglitazone) labels now contain updated information about cardiovascular risks and use in certain patients.

37. US Food and Drug Administration. FDA Drug Safety Communication: Update to ongoing safety review of Actos (pioglitazone) and increased risk of bladder cancer.

38. European Medicines Agency recommends new contra-indications and warnings for pioglitazone to reduce small increased risk of bladder cancer.

39. Drucker DJ, Nauck MA (2006) The incretin system: glucagon-like peptide-1 receptor agonists and dipeptidyl peptidase-4 inhibitors in type 2 diabetes. Lancet 368: 1696-1705.

40. Aso Y, Ozeki N, Terasawa T, Naruse R, Hara K, et al. (2012) Serum leve of soluble CD26/dipeptidyl peptidase-4 (DPP-4) predicts the response to sitagliptin, a DPP-4 inhibitor, in patients with type 2 diabetes controlled inadequately by metformin and/or sulfonylurea. Transl Res 159: 25-31.

41. Nauck MA, Heimesaat MM, Orskov C, Holst JJ, Ebert R, et al. (1993) Preserved incretin activity of glucagon-like peptide 1 [7-36 amide] but not of synthetic human gastric inhibitory polypeptide in patients with type-2 diabetes mellitus. $J$ Clin Invest 91: 301-307.

42. Angeli FS, Shannon RP (2014) Incretin-based therapies: can we achieve glycemic control and cardioprotection? J Endocrinol 221: T17-30. 
43. Fadini GP, Boscaro E, Albiero M, Menegazzo L, Frison V, et al. (2010) The oral dipeptidyl peptidase-4 inhibitor sitagliptin increases circulating endothelial progenitor cells in patients with type 2 diabetes: possible role of stromal-derived factor-1a. Diabetes Care 33: 1607-1609.

44. Potter LR, Abbey-Hosch S, Dickey DM (2006) Natriuretic peptides, their receptors, and cyclic guanosine monophosphate-dependent signaling functions. Endocr Rev 27: 47-72.

45. Buse JB, Bergenstal RM, Glass LC, Heilmann CR, Lewis MS, et al. (2011) Use of twice-daily exenatide in basal insulin-treated patients with type 2 diabetes: a randomized, controlled trial. Ann Intern Med 154: 103-112.

46. Zinman B, Hoogwerf BJ, Duran Garcia S, Milton DR, Giaconia JM, et al. (2007) The effect of adding exenatide to a thiazolidinedione in suboptimally controlled type 2 diabetes: a randomized trial. Ann Intern Med 146: 477-485.

47. DeFronzo RA, Ratner RE, Han J, Kim DD, Fineman MS, et al. (2005) Effects of exenatide (exendin-4) on glycemic control and weight over 30 weeks in metformin-treated patients with type 2 diabetes. Diabetes Care 28: 1092-1100.

48. Kendall DM, Riddle MC, Rosenstock J, Zhuang D, Kim DD, et al. (2005) Effects of exenatide (exendin-4) on glycemic control over 30 weeks in patients with type 2 diabetes treated with metformin and a sulfonylurea. Diabetes Care 28 1083-1091.

49. Mari A, Degn K, Brock B, Rungby J, Ferrannini E, et al. (2007) Effects of the long-acting human glucagon-like peptide-1 analog liraglutide on beta-cell function in normal living conditions. Diabetes Care 30: 2032-2033.

50. Marre M, Shaw J, Brandle M, Bebakar WM, Kamaruddin NA, et al. (2009) Liraglutide, a once-daily human GLP-1 analogue, added to a sulphonylurea over 26 weeks produces greater improvements in glycaemic and weight contro compared with adding rosiglitazone or placebo in subjects with type 2 diabetes (LEAD-1 SU). Diabet Med 26: 268-278.

51. Pencek R, Brunell SC, Li Y, Hoogwerf BJ, Malone J (2012) Exenatide once weekly for the treatment of type 2 diabetes mellitus: clinical results in subgroups of patients using different concomitant medications. Postgrad Med 124: 33-40.

52. Russell-Jones D, Vaag A, Schmitz O, Sethi BK, Lalic N, et al. (2009) Liraglutide vs insulin glargine and placebo in combination with metformin and sulfonylurea therapy in type 2 diabetes mellitus (LEAD- 5 met+SU): a randomised controlled trial. Diabetologia 52: 2046-2055.

53. Byetta ${ }^{\circledR}$ (exenatide). Full Prescribing Information, Amylin Pharmaceuticals, Inc., San Diego, CA, 2011.

54. Victoza ${ }^{\circledR}$ (liraglutide [rDNA origin]). Full Prescribing Information, Novo Nordisk Inc., Princeton, NJ, 2012.

55. Kim D, MacConell L, Zhuang D, Kothare PA, Trautmann M, et al. (2007) Effects of once-weekly dosing of a long-acting release formulation of exenatide on glucose control and body weight in subjects with type 2 diabetes. Diabetes Care 30: 1487-1493.

56. Aschner P, Kipnes MS, Lunceford JK, Sanchez M, Mickel C, et al. (2006) Effect of the dipeptidyl peptidase-4 inhibitor sitagliptin as monotherapy on glycemic control in patients with type 2 diabetes. Diabetes Care 29: 2632-2637.

57. Del Prato S, Barnett AH, Huisman H, Neubacher D, Woerle HJ, et al. (2011) Effect of linagliptin monotherapy on glycaemic control and markers of beta-cel function in patients with inadequately controlled type 2 diabetes: a randomized controlled trial. Diabetes Obes Metab 13: 258-267.

58. Rosenstock J, Aguilar-Salinas C, Klein E, Nepal S, List J, et al. (2009) Effect of saxagliptin monotherapy in treatment-naive patients with type 2 diabetes. Curr Med Res Opin 25: 2401-2411

59. DeFronzo RA, Fleck PR, Wilson CA, Mekki Q (2008) Efficacy and safety of the dipeptidyl peptidase-4 inhibitor alogliptin in patients with type 2 diabetes and inadequate glycemic control: a randomized, double-blind, placebo-controlled study. Diabetes Care 31: 2315-2317.

60. Charbonnel B, Karasik A, Liu J, Wu M, Meininger G (2006) Efficacy and safety of the dipeptidyl peptidase-4 inhibitor sitagliptin added to ongoing metformin therapy in patients with type 2 diabetes inadequately controlled with metformin alone. Diabetes Care 29: 2638-2643.

61. DeFronzo RA, Hissa MN, Garber AJ, Luiz Gross J, Yuyan Duan R, et al. (2009) The efficacy and safety of saxagliptin when added to metformin therapy in patients with inadequately controlled type 2 diabetes with metformin alone. Diabetes Care 32: 1649-1655.
62. Scott R, Loeys T, Davies MJ, Engel SS, Sitagliptin Study 801 Group (2008) Efficacy and safety of sitagliptin when added to ongoing metformin therapy in patients with type 2 diabetes. Diabetes Obes Metab 10: 959-969.

63. Taskinen MR, Rosenstock J, Tamminen I, Kubiak R, Patel S, et al. (2011) Safety and efficacy of linagliptin as add-on therapy to metformin in patients with type 2 diabetes: a randomized, double-blind, placebo-controlled study. Diabetes Obes Metab 13: 65-74

64. Nauck MA, Ellis GC, Fleck PR, Wilson CA, Mekki Q (2009) Efficacy and safety of adding the dipeptidyl peptidase- 4 inhibitor alogliptin to metformin therapy in patients with type 2 diabetes inadequately controlled with metformin monotherapy: a multicentre, randomised, double-blind, placebo-controlled study. Int J Clin Pract 63: 46-55.

65. Chacra AR, Tan GH, Apanovitch A, Ravichandran S, List J, et al. (2009) Saxagliptin added to a submaximal dose of sulphonylurea improves glycaemic control compared with uptitration of sulphonylurea in patients with type 2 diabetes: a randomised controlled trial. Int J Clin Pract 63: 1395-1406.

66. Hermansen K, Kipnes M, Luo E, Fanurik D, Khatami H, et al. (2007) Efficacy and safety of the dipeptidyl peptidase-4 inhibitor, sitagliptin, in patients with type 2 diabetes mellitus inadequately controlled on glimepiride alone or on glimepiride and metformin. Diabetes Obes Metab 9: 733-745.

67. Owens DR, Swallow R, Dugi KA, Woerle HJ (2011) Efficacy and safety of linagliptin in persons with type 2 diabetes inadequately controlled by a combination of metformin and sulphonylurea: a 24 -week randomized study. Diabet Med 28: 1352-1361.

68. Pratley RE, Kipnes MS, Fleck PR, Wilson C, Mekki Q, et al. (2009) Efficacy and safety of the dipeptidyl peptidase-4 inhibitor alogliptin in patients with type 2 diabetes inadequately controlled by glyburide monotherapy. Diabetes Obes Metab 11: 167-176.

69. Rosenstock J, Brazg R, Andryuk PJ, Lu K, Stein P (2006) Efficacy and safety of the dipeptidyl peptidase-4 inhibitor sitagliptin added to ongoing pioglitazone therapy in patients with type 2 diabetes: a 24 -week, multicenter, randomized, double-blind, placebo-controlled, parallel-group study. Clin Ther 28: 1556-1568.

70. Hollander P, Li J, Allen E, Chen R, CV181-013 Investigators (2009) Saxagliptin added to a thiazolidinedione improves glycemic control in patients with type 2 diabetes and inadequate control on thiazolidinedione alone. J Clin Endocrinol Metab 94: 4810-4819.

71. Pratley RE, Reusch JE, Fleck PR, Wilson CA, Mekki Q, et al. (2009) Efficacy and safety of the dipeptidyl peptidase- 4 inhibitor alogliptin added to pioglitazone in patients with type 2 diabetes: a randomized, double-blind, placebo-controlled study. Curr Med Res Opin 25: 2361-2371.

72. Barnett AH, Charbonnel B, Donovan M, Fleming D (2012) Effect of saxagliptin as add-on therapy in patients with poorly controlled type 2 diabetes on insulin alone or insulin combined with metformin. Curr Med Res Opin 28: 513-523.

73. Vilsboll T, Rosenstock J, Yki-Jarvinen H, Cefalu WT, Chen Y, et al. (2010) Efficacy and safety of sitagliptin when added to insulin therapy in patients with type 2 diabetes. Diabetes Obes Metab 12: 167-177.

74. Rosenstock J, Rendell MS, Gross JL, Fleck PR, Wilson CA, et al. (2009) Alogliptin added to insulin therapy in patients with type 2 diabetes reduces $\mathrm{HbA}(1 \mathrm{C})$ without causing weight gain or increased hypoglycaemia. Diabetes Obes Metab 11: 1145-1152.

75. Jadzinsky M, Pfutzner A, Paz-Pacheco E, Xu Z, Allen E, et al. (2009) Saxagliptin given in combination with metformin as initial therapy improves glycaemic control in patients with type 2 diabetes compared with either monotherapy: a randomized controlled trial. Diabetes Obes Metab 11: 611-622.

76. Gomis R, Espadero RM, Jones R, Woerle HJ, Dugi KA (2011) Efficacy and safety of initial combination therapy with linagliptin and pioglitazone in patients with inadequately controlled type 2 diabetes: a randomized, double-blind placebo-controlled study. Diabetes Obes Metab 13: 653-661.

77. Yoon KH, Shockey GR, Teng R, Golm GT, Thakkar PR, et al. (2011) Effect of initial combination therapy with sitagliptin, a dipeptidyl peptidase-4 inhibitor, and pioglitazone on glycemic control and measures of beta-cell function in patients with type 2 diabetes. Int J Clin Pract 65: 154-164.

78. Rosenstock J, Inzucchi SE, Seufert J, Fleck PR, Wilson CA, et al. (2010) Initial combination therapy with alogliptin and pioglitazone in drug-naive patients with type 2 diabetes. Diabetes Care 33: 2406-2408.

79. Karagiannis T, Paschos P, Paletas K, Matthews DR, Tsapas A (2012) Dipeptidy peptidase- 4 inhibitors for treatment of type 2 diabetes mellitus in the clinical setting: systematic review and meta-analysis. BMJ 344: e1369. 
80. Januvia $\AA^{2}$ (sitagliptin). Full Prescribing Information, Whitehouse Station, NJ, Merck \& Co., Inc., 2014.

81. Onglyza® (saxagliptin). Full Prescribing Information, Bristol-Myers Squibb Company, Princeton, NJ, 2013.

82. Tradjenta ${ }^{\circledR}$ (linagliptin). Full Prescribing Information, Boehringer Ingelheim Pharmaceuticals, Inc., Ridgefield, CT, 2013.

83. Standl E, Schnell O (2012) Alpha-glucosidase inhibitors 2012 - cardiovascular considerations and trial evaluation. Diab Vasc Dis Res 9: 163-169.

84. Fonseca VA, Handelsman Y, Staels B (2010) Colesevelam lowers glucose and lipid levels in type 2 diabetes: the clinical evidence. Diabetes Obes Metab 12 384-392.

85. Gaziano JM, Cincotta AH, O’Connor CM, Ezrokhi M, Rutty D, et al. (2010) Randomized clinical trial of quick-release bromocriptine among patients with type 2 diabetes on overall safety and cardiovascular outcomes. Diabetes Care 33: 1503-1508.

86. Schmitz O, Brock B, Rungby J (2004) Amylin agonists: a novel approach in the treatment of diabetes. Diabetes 53: S233-238.

87. Invokana ${ }^{\mathrm{TM}} \quad$ (canagliflozin). Full Prescribing Information, Janssen Pharmaceuticals, Inc., Titusville, NJ, 2013.

88. Sha S, Devineni D, Ghosh A, Polidori D, Chien S, et al. (2011) Canagliflozin, a novel inhibitor of sodium glucose co-transporter 2 , dose dependently reduces calculated renal threshold for glucose excretion and increases urinary glucose excretion in healthy subjects. Diabetes Obes Metab 13: 669-672.

89. Clar C, Gill JA, Court R, Waugh NR (2012) Systematic review of SGLT2 receptor inhibitors in dual or triple therapy in type 2 diabetes. BMJ Open 2: e001007.

90. UK Prospective Diabetes Study Group (1995) U.K. Prospective Diabetes Study 16. Overview of 6 years' therapy of type II diabetes: a progressive disease. Diabetes 44: 1249-1258.

91. Turner RC, Cull CA, Frighi V, Holman RR (1999) Glycemic control with diet sulfonylurea, metformin, or insulin in patients with type 2 diabetes mellitus: progressive requirement for multiple therapies (UKPDS 49). UK Prospective Diabetes Study (UKPDS) Group. JAMA 281: 2005-2012.

92. McIntosh B, Cameron C, Singh SR, Yu C, Ahuja T, et al. (2011) Second-line therapy in patients with type 2 diabetes inadequately controlled with metformin monotherapy: a systematic review and mixed-treatment comparison metaanalysis. Open Med 5: e35-48.

93. Phung OJ, Scholle JM, Talwar M, Coleman CI (2010) Effect of noninsulin antidiabetic drugs added to metformin therapy on glycemic control, weight gain and hypoglycemia in type 2 diabetes. JAMA 303: 1410-1418.

94. Bell DS, Dharmalingam M, Kumar S, Sawakhande RB (2011) Triple oral fixeddose diabetes polypill versus insulin plus metformin efficacy demonstration study in the treatment of advanced type 2 diabetes (TrIED study-II). Diabetes Obes Metab 13: 800-805

95. Charpentier G, Halimi S, F-PIO-100 Study Investigators (2009) Earlier triple therapy with pioglitazone in patients with type 2 diabetes. Diabetes Obes Metab 11: 844-854

96. Roberts VL, Stewart J, Issa M, Lake B, Melis R (2005) Triple therapy with glimepiride in patients with type 2 diabetes mellitus inadequately controlled by metformin and a thiazolidinedione: results of a 30-week, randomized, doubleblind, placebo-controlled, parallel-group study. Clin Ther 27: 1535-1547.

97. Rosenstock J, Sugimoto D, Strange P, Stewart JA, Soltes-Rak E, et al. (2006) Triple therapy in type 2 diabetes: insulin glargine or rosiglitazone added to combination therapy of sulfonylurea plus metformin in insulin-naive patients. Diabetes Care 29: 554-559.

98. Scheen AJ, Tan MH, Betteridge DJ, Birkeland K, Schmitz O, et al. (2009) Long-term glycaemic control with metformin-sulphonylurea-pioglitazone triple therapy in PROactive (PROactive 17). Diabet Med 26: 1033-1039.

99. Moses RG, Kalra S, Brook D, Sickler J, Visvanathan J, et al. (2012) Saxagliptin (SAXA) effectively reduces $\mathrm{HbA} 1 \mathrm{c}$ and is well tolerated when added to a combination of metformin (MET) and sulfonlyurea (SU) [abstract]. Diabetes 61 A282.

100. Holman RR, Thorne KI, Farmer AJ, Davies MJ, Keenan JF, et al. (2007) Addition of biphasic, prandial, or basal insulin to oral therapy in type 2 diabetes. N Engl J Med 357: 1716-1730.
101.Strowig SM, Aviles-Santa ML, Raskin P (2002) Comparison of insulin monotherapy and combination therapy with insulin and metformin or insulin and troglitazone in type 2 diabetes. Diabetes Care 25: 1691-1698.

102. Wulffele MG, Kooy A, Lehert P, Bets D, Ogterop JC, et al. (2002) Combination of insulin and metformin in the treatment of type 2 diabetes. Diabetes Care 25: $2133-2140$

103. Yki-Jarvinen H, Duran-Garcia S, Pinnetti S, Bhattacharya D, Thiemann S, et al. (2012) Efficacy and safety of linagliptin as add-on therapy to basal insulin in patients with type 2 diabetes [abstract]. Diabetes 61: A255

104. Goldstein BJ, Feinglos MN, Lunceford JK, Johnson J, Williams-Herman DE (2007) Effect of initial combination therapy with sitagliptin, a dipeptidy peptidase-4 inhibitor, and metformin on glycemic control in patients with type 2 diabetes. Diabetes Care 30: 1979-1987.

105. Haffner SM, Lehto S, Ronnemaa T, Pyorala K, Laakso M (1998) Mortality from coronary heart disease in subjects with type 2 diabetes and in nondiabetic subjects with and without prior myocardial infarction. N Engl J Med 339: 229 234.

106. Juutilainen A, Lehto S, Ronnemaa T, Pyorala K, Laakso M (2005) Type 2 diabetes as a "coronary heart disease equivalent": an 18-year prospective population-based study in Finnish subjects. Diabetes Care 28: 2901-2907.

107. Schramm TK, Gislason GH, Kober L, Rasmussen S, Rasmussen JN, et al (2008) Diabetes patients requiring glucose-lowering therapy and nondiabetics with a prior myocardial infarction carry the same cardiovascular risk: a population study of 3.3 million people. Circulation 117: 1945-1954.

108. Monami M, Ahren B, Dicembrini I, Mannucci E (2013) Dipeptidyl peptidase-4 inhibitors and cardiovascular risk: a meta-analysis of randomized clinical trials. Diabetes Obes Metab 15: 112-120.

109. Frederich R, Alexander JH, Fiedorek FT, Donovan M, Berglind N, et al. (2010) A systematic assessment of cardiovascular outcomes in the saxagliptin drug development program for type 2 diabetes. Postgrad Med 122: 16-27.

110. Johansen OE, Neubacher D, von Eynatten M, Patel S, Woerle HJ (2012) Cardiovascular safety with linagliptin in patients with type 2 diabetes mellitus: a pre-specified, prospective, and adjudicated meta-analysis of a phase 3 programme. Cardiovasc Diabetol 11: 3.

111. Cobble ME, Frederich $\mathrm{R}$ (2012) Saxagliptin for the treatment of type 2 diabetes mellitus: assessing cardiovascular data. Cardiovasc Diabetol 11: 6

112. Williams-Herman D, Engel SS, Round E, Johnson J, Golm GT, et al. (2010) Safety and tolerability of sitagliptin in clinical studies: a pooled analysis of data from 10,246 patients with type 2 diabetes. BMC Endocr Disord 10: 7. PM:20412573 file://K:IRefMan DatabaselElectronic References|20677 Williams-Herman.pdf.

113. CAROLINA: cardiovascular outcome study of linagliptin versus glimepiride in patients with type 2 diabetes. ClinicalTrials.gov.

114. Mosenzon O, Raz I, Scirica BM, Hirshberg B, Stahre Cl, et al. (2013) Baseline characteristics of patient population in the Saxagliptin Assessment of Vascular Outcomes Recorded in Patients With Diabetes Mellitus (SAVOR)-TIMI 53 trial. Diabetes Metab Res Rev 29: 417-426.

115. Scirica BM, Bhatt DL, Braunwald E, Steg PG, Davidson J, et al. (2011) The design and rationale of the Saxagliptin Assessment of Vascular Outcomes Recorded in Patients With Diabetes Mellitus-Thrombolysis in Myocardial Infarction (SAVOR-TIMI) 53 study. Am Heart J 162: 818-825.

116. White WB, Bakris GL, Bergenstal RM, Cannon CP, Cushman WC, et al. (2011) Examination of cardiovascular outcomes with alogliptln versus standard of care in patients with type 2 diabetes mellitus and acute coronary syndrome (EXAMINE): a cardiovascular safety study of the dipeptidyl peptidase 4 inhibitor alogliptin in patients with type 2 diabetes with acute coronary syndrome. Am Heart J 162: 620-626

117. Scirica BM, Bhatt DL, Braunwald E, Steg PG, Davidson J, et al. (2013) Saxagliptin and cardiovascular outcomes in patients with type 2 diabetes mellitus. N Engl J Med 369: 1317-1326.

118. White WB, Cannon CP, Heller SR, Nissen SE, Bergenstal RM, et al. (2013) Alogliptin after acute coronary syndrome in patients with type 2 diabetes. $\mathrm{N}$ Engl J Med 369: 1327-1335.

119. White WB (2013) Cardiovascular outcomes with alogliptin in patients with type 2 diabetes mellitus and recent acute coronary syndromes. Proceedings of the European Association for the Study of Diabetes. 